UDC 541.543 .42

\title{
EXTRACTION CONCENTRATING OF SCANDIUM (III) IN COMPLEX FORM WITH 2-HYDROXY-5-T-BUTYLPHENOL-4'-METOXYAZOBENZENE AND ITS DETERMINATION BY ATOMIC-ABSORPTION SPECTROMETRY
}

\author{
A.M.Pashajanov, S.I.Niftaliyev*, M.M.Agamaliyeva, S.M.Bayramov, G.G.Abbasova, \\ Z.A.Mamedova \\ M.Nagiyev Institute of Catalysis and Inorganic Chemistry, NAS of Azerbaijan \\ *Voronezh State Technological Academy, Russia \\ aydin.pashajanov@gmail.com
}

Received 23.06.2021

Accepted 12.08.2021

\begin{abstract}
Complexation of scandium 2-hydroxy-5-T-butylphenol-4'-metoxyazobenzene (HR) was studied by atomic-absorption and spectrophotometric methods. Optimum conditions of formation and extraction of the complex were found. Maximum light absorbance of a complex in n-butanol is in the range of $470 \div 480 \mathrm{~nm}$. Molar absorption coefficient equals to (2.2-3.0) $10^{4}$. Stability constant of scandium in nbutanol is $\beta_{\mathrm{л}}=2.8 \cdot 10^{10}$. Selective and sensitive techniques of extraction-atomic absorption determination of scandium in soils were developed.
\end{abstract}

Keywords: scandium, atomic-absorption method, extraction, complexation.

doi.org/10.32737/0005-2531-2021-4-49-52

\section{Introduction}

Synthesis and study of new organic reagents that can reduce the duration of determining elements and increase the accuracy of analysis are actual tasks of spectrophotometry. In this regard promising reagents on scandium ions for photometrical and extraction-atomicabsorption determination are nitrogen containing azo-compounds [1-5]. It is known that azocompounds based on para-tret-butylphenol and pyrogallol are prospective reagents for determination of ions of a number metals $[6,7]$. This was caused by the fact that hydroxyl group of para-tret-butylphenol creates the possibility of forming the complexes with direct involvement of nitrogen atom of azo group caused by metalnitrogen bond. That's why the discovery of new analytical possibilities of azo-compounds synthesized on the basis of para-tret-butylphenol was of practical interest. Preconcentration is applied to reduce the detection limit of scandium in different objects. Scandium is especially often concentrated by extraction of its complexes with methylisobutylketone or ammonium pyrolidiniumthiocarbamate [5].

We studied the complexation of scandium with HR, as well as extraction concentration conditions of scandium and following atomicadsorption determination in soils.

\section{Experimental part}

Reagents and instruments. Primary solution of scandium with concentration of $1.2 \cdot 10^{-2}$ $M$ was prepared by dissolution of accurate weight of metallic scandium by technique [8]. More diluted solutions of scandium were prepared by diluting the primary solution. The solution HR with concentration of $3.5 \cdot 10^{-4} \mathrm{M}$ was prepared by dissolution of accurate weight of HR in ethanol.

Reagent 2-hydroxy-5-T-butylphenol-4'metoxyazobenzene (HR) was synthesized by technique [9]. Reagent is a monoacid, it has general structural formula.

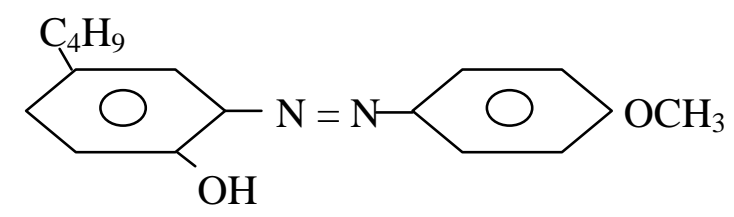

The composition and structure of the reagent were determined by elemental analysis, as well as by methods of IR-, UV-spectroscopy. This is a brown colored crystalline substance which is dissolved in methanol, ethanol, propa- 
nol, isopropanol, acetone and other solvents. Additional purification of the reagent was conducted by recrystallization from ethyl alcohol.

IR-spectrum $3400 \mathrm{~cm}^{-1}$ (O-H arom.), $2960 \mathrm{~cm}^{-1}\left(\mathrm{C}-\mathrm{H}\right.$ from $\left.\mathrm{CH}_{3}\right), 3060 \mathrm{~cm}^{-1}(\mathrm{C}-\mathrm{H}$ arom.), 1582, 1496, $1464 \mathrm{~cm}^{-1}(\mathrm{C}=\mathrm{C}$ arom. $)$, $1400 \mathrm{~cm}^{-1}(\mathrm{~N}=\mathrm{N}) .1256 \mathrm{~cm}^{-1}(\mathrm{C}-\mathrm{N}), 1168 \mathrm{~cm}^{-1}$ (C-C), $1104 \mathrm{~cm}^{-1}$ (arom. -O-C). For creation of necessary values of $\mathrm{pH}$ we used ammonium acetate $(\mathrm{pH} 3-11)$ and fixanal $\mathrm{HCl}(\mathrm{pH} \mathrm{1-2)}$ buffer solutions; $\mathrm{pH}$ was controlled by EV-74. Ionic strength of solutions $(\mu=0,1)$ was supported with constant solution of $\mathrm{KNO}_{3}$. We used benzene, toluene, chloroform, carbon tetrachloride, dichlorothane, $n$-butanol and hexane as organic solvents.

Optical density of extractants was measured on photoelectrometer KFK-2 and spectrophotometer SF-46. Atomic absorption of scandium was measured on atomic-absorption spectrophotometer AAS-30 Carl, ZEISs JENA. As light sources standard hollow cathode lamps were used. Optimum measurement conditions are listed in Table 1.

Table 1. Conditions of atomic-adsorption determination of scandium

\begin{tabular}{|c|c|c|c|c|}
\hline $\begin{array}{c}\text { Wave- } \\
\text { length, } \\
\mathrm{nm}\end{array}$ & $\begin{array}{c}\text { Slot } \\
\text { width, } \\
\mathrm{nm}\end{array}$ & $\begin{array}{c}\text { Lamp } \\
\text { current, } \\
\mathrm{mA}\end{array}$ & $\begin{array}{c}\text { Acety- } \\
\text { lene flow, } \\
\text { l/h }\end{array}$ & $\begin{array}{c}\text { Consumption } \\
\text { of nitrogen } \\
\text { oxide, } 1 / \mathrm{h}\end{array}$ \\
\hline 390.7 & 0.5 & 20 & 200 & 180 \\
\hline
\end{tabular}

\section{Technique}

A certain amount of standard solution of scandium, $10 \mathrm{ml}$ of buffer solution with certain $\mathrm{pH}, 1 \mathrm{ml}$ of reagent solution were poured into a separatory funnel or stoppered tubes, diluted with distilled water to $20 \mathrm{ml}$, and resulting compound of $10 \mathrm{ml} \mathrm{n}$-butanol was extracted and mixed one minute. After complete separation of phases extract was sprayed into the flame of acetylene-nitrogen oxide and atomic-absorption of scandium was measured under optimum conditions (Table 1).

\section{Results and discussion}

Spectrophotometric study of the reaction. During the interaction of scandium (III) with HR in hydrochloride solutions the complexes are formed which can be extracted with organic solvents. The limit of $\mathrm{pH} 2-3$ is optimum for full formation of a complex of scandium (Figure 1). The nature of acids $(\mathrm{HCl}$, $\mathrm{H}_{2} \mathrm{SO}_{4}$ ) do not almost influence on the reaction.

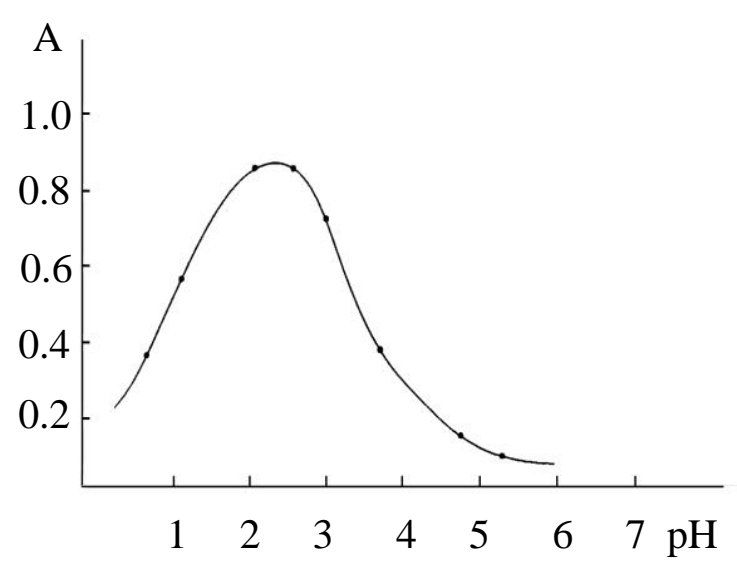

Fig. 1. Influence of $\mathrm{pH}$ on complexation of Sc(III). $C_{\mathrm{HR}}=3.5 \cdot 10^{-4} \mathrm{M}, C_{\mathrm{Sc}}=1.2 \cdot 10^{-2} \mathrm{M}, \lambda=$ $480 \mathrm{~nm}, V_{\text {оrg }}=10$ мл, $l=0.5 \mathrm{~cm}, \mathrm{KFK}-2, \mathrm{SF}-46$.

Absorption spectrum of the complex. Under optimum conditions we have taken absorption spectrum of the complex the maximum of which is observed at $470-480 \mathrm{~nm}$, but maximum of the reagent is observed at $370-380 \mathrm{~nm}$. Thus, the complexation is accompanied by bathochromic shift (Figure 2). View of absorption spectrum of extractant indicates the formation of one complex.

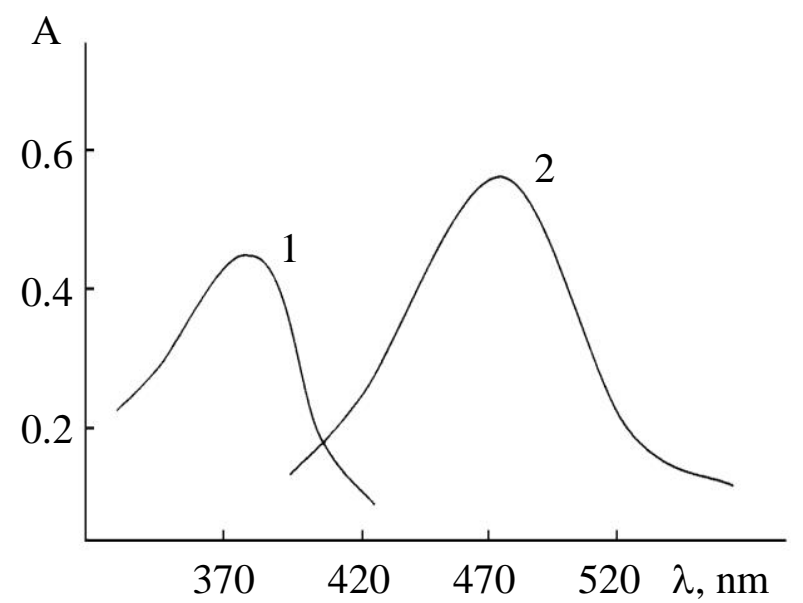

Fig. 2. Absorption spectrum of extractants of reagents (1) and complex $\mathrm{Sc}(\mathrm{III})$ (2): $C_{\mathrm{HR}}=3.5 \cdot 10^{-4} \mathrm{M}$, $C_{\mathrm{Sc}}=1.2 \cdot 10^{-2} \mathrm{M}, V_{\text {org }}=10 \mathrm{ml}, l=0.5 \mathrm{~cm}, \mathrm{KFK}-2, \mathrm{SF}-46$.

Composition and physical-chemical properties of the complex. Molar ratio of components in the complex which was established by 
straight-line method of Asmus and equilibrium shift, equals to $1: 2$ [10]. Stability constant of the complex in chloroform $2,8 \cdot 10^{10}$ and equilibrium constant of complexation reaction $3.2 \cdot 10^{4}$ at $\mathrm{pH}=4.0$ were calculated by spectrophotometric data for chloroform and $n$-butanol solutions of the complex by using dependence of light absorbance of solutions on $\mathrm{pH}$.

Molar absorption coefficient of scandium, calculated by Tolmachev method [10] equals to $(2.2-3.0) \cdot 10^{4}$. Calibration chart is linear at concentrations of scandium $1.0 \div 10.0 \mathrm{mkg} / \mathrm{ml}$.

The influence of different ions on the results of determination of scandium is shown in Table 2.

Table 2. Influence of accompanying ions on the results of determining scandium ( $5 \mathrm{mkg} / \mathrm{mg}$ of scandium was added)

\begin{tabular}{|c|c|c|c|}
\hline $\begin{array}{c}\text { Accompa- } \\
\text { nying ion }\end{array}$ & $\begin{array}{c}\text { Permissible } \\
\text { amount of } \\
\text { accompanying } \\
\text { ion, mg }\end{array}$ & $\begin{array}{c}\text { Accompa- } \\
\text { nying ion }\end{array}$ & $\begin{array}{c}\text { Permissible } \\
\text { amount of } \\
\text { accompany- } \\
\text { ing ion, mg }\end{array}$ \\
\hline $\mathrm{Na}(\mathrm{I})$ & 200 & $\mathrm{Al}(\mathrm{III})$ & 10 \\
\hline $\mathrm{K}(\mathrm{I})$ & 200 & $\mathrm{Fe}(\mathrm{III})$ & 15 \\
\hline $\mathrm{Mg}(\mathrm{II})$ & 100 & $\mathrm{~V}(\mathrm{~V})$ & 10 \\
\hline $\mathrm{Ca}(\mathrm{II})$ & 50 & $\mathrm{~W}(\mathrm{VI})$ & 15 \\
\hline $\mathrm{Ba}(\mathrm{II})$ & 20 & $\mathrm{Cl}^{-}$ & 4 \\
\hline $\mathrm{Zn}$ (II) & 10 & $\mathrm{Br}^{-}$ & 5 \\
\hline $\mathrm{Cd}(\mathrm{II})$ & 10 & $\mathrm{~J}^{-}$ & 5 \\
\hline $\mathrm{Mn}(\mathrm{II})$ & 20 & $\mathrm{SO}_{4}^{-2}$ & 10 \\
\hline $\mathrm{Co}$ (II) & 10 & $\mathrm{PO}_{4}^{-3}$ & 10 \\
\hline $\mathrm{Ni}(\mathrm{II})$ & 50 & $\mathrm{NO}_{3}^{-}$ & 0.5 \\
\hline $\mathrm{Cu}(\mathrm{II})$ & 10 & $\mathrm{CO}_{3}^{-2}$ & 10 \\
\hline $\mathrm{Pb}(\mathrm{II})$ & 15 & & \\
\hline
\end{tabular}

Influence of foreign ions. Selectivity of extraction-atomic absorption determination of scandium was studied with HR. It was established that large amount of alkali alkali-earth elements and rare-earth elements do not interfere with the determination of scandium.

Extraction of the complex. Extractability of the complex was evaluated by distribution coefficient and extraction degree. Equilibrium concentration of scandium in aqueous phase was found by difference. $96 \%$ of scandium is extracted with single extraction with $n$-butanol. Increase in volume of aqueous phase up to 30 $\mathrm{ml}$ does not essentially influence on optical density of extractants in $n$-butanol. Maximum opti- cal density of the solution is achieved during keeping the complex 1-2 min. The complex is stable within two days. When the concentration of the reagent increases optical density of organic phase is enhanced and achieves plateau at the concentration of $3.5-4.2 \cdot 10^{-4} \mathrm{M}$ HR.

When spraying directly the extracts into burner flame, organic solvents must be fuel. Atomic absorption of scandium is reduced during the use of halogen containing solvents. Nbutanol was turned to be more suitable for atomic-absorption analysis. It does not change burning regime of a flame and does not create background in the field of analytical line of scandium, supports stable burning which allows us to determine scandium in direct spraying of extractant into flame. For the first time we used direct input of organic extractant into flame for scandium ions to increase sensitivity.

Preliminary extraction of scandium and direct input of extractants into flame allow us to increase selectivity and sensitivity of the analysis.

Practically full extraction of the complex of scandium from hydrochloride medium was used for development of extraction-atomic-absorption determination of scandium in soils. Selective technique for extraction-atomic-absorption determination of scandium in soils was developed.

Determination. Soil sample $(2-4$ г) was put into platinum dish, wetted with water, $10 \mathrm{ml}$ conc. $\mathrm{HNO}_{3}, 10 \mathrm{ml} \mathrm{HF}$ were poured and $30 \%$ $\mathrm{H}_{2} \mathrm{O}_{2}$ was added drop by drop. The content was heated and filtered, the solvent was evaporated dry, the residue was treated twice with $5 \mathrm{ml}$ conc. $\mathrm{HNO}_{3}$ and dissolved in $10-20 \mathrm{ml}$ hot water with heating till dissolution of salts. The solution was placed into $100 \mathrm{ml}$ measuring flask and diluted with water to the mark.

Aliquot $(10 \mathrm{ml})$ part of solvent was placed into separatory funnel, necessary acidity ( $\mathrm{pH}$ 2) was created by $\mathrm{HCl}, 1 \mathrm{ml}$ of ethanol solution $\mathrm{HR}$ was added, was diluted with distilled water to $20 \mathrm{ml}$ and formed compound of $10 \mathrm{ml}$ $n$-butanol was extracted by mixing 1 min organic phase was separated, extractant was sprayed into flame of acetylene-nitrogen oxide and atomic absorption of scandium was measured. The content of scandium was found by calibration chart. 
Correctness of the technique was tested on standard samples of soil SP-1, SP-3. Results of determining scandium are given in the Table 3.

Table 3. Results of extraction-atomic-absorption determination of $\mathrm{Sc}$ (III) in standard samples of soils $(n=5$, $p=0.95$ ).

\begin{tabular}{|c|c|c|c|}
\hline \multirow{2}{*}{$\begin{array}{c}\text { Standard } \\
\text { sample }\end{array}$} & \multicolumn{2}{|c|}{ Content, Sc, \% } & \multirow{2}{*}{ Sr } \\
\cline { 2 - 3 } & by nameplate & found & \\
\hline SP-1 & 0.0012 & $0.0012 \pm 0,0001$ & 0.020 \\
\hline SP-2 & 0.0014 & $0.0014 \pm 0,0001$ & 0.016 \\
\hline
\end{tabular}

\section{Conclusions}

Complexation of Sc(III) with 2-hydroxy-5T-butylphanol-4'-metoxy-azobenzene (HR) was studied. Optimum conditions of formation of the complex and its extraction with chloroform and $n$ butanol were found. Molar absorption coefficient equals to (2.2-3.0)'10 ${ }^{4}$. Stability constant $f$ the complex of scandium in $n$-butanol is $\beta_{\pi}=2.8 \cdot 10^{10}$. Beer's law is observed at concentrations of scandium 1-10 $\mathrm{mkg} / \mathrm{ml}$. Determination technique of scandium in soils was developed.

\section{References}

1. Ivanov V.M. Geterotsiklicheskiye azotsoderzhashchiye azosoyedineniya. M.: Nauka, 1982. $229 \mathrm{~s}$.
2. Sharlo G. Metody analiticheskoy khimii. M.-L.: Khimiya, 1965. $812 \mathrm{~s}$.

3. Umland F., Yansen A., Tiring D., Vyunsh G. Kompleksy soyedineniya $\mathrm{v}$ analiticheskoy khimii. M.: Mir, 1975. 245 s.

4. Zolotov Yu.A., Kuzmin N.M. Ekstraktsionnoye kontsentrirovaniye. M.: Khimiya, 1971. 271 s.

5. Prays V. Analiticheskaya atomno-absorbtsionnaya spektroskopiya. M.: Mir, 1976. 271s.

6. Pashadzhanov A.M. Ekstraktsiya i atomno-absorbtsionnoye opredeleniye molibdena(VI) s pomoshch'yu 2-gidroksi-5-tret-butilfenol-2'-metilazobenzola. Zhurn. analit. khimii. 2006. T. 61. № 8. S. 1-4.

7. Gadzhiyeva S.R. Aliyeva T.I., Chyragov F.M. Spektrofotometricheskoye opredeleniye skandiya (III)-bis-(2,3,4-trioksifenilazobenzidinom i difenilguanidom. Zhurn. analit. analit. khimii. 2006. T. 61. № 8. S. 803-806.

8. Lazarev A.I., Kharlamov I.P., Yakovlev P.Ya. Spravochnik khimika-analitika. M.: Metallurgiya, 1976. $184 \mathrm{~s}$.

9. Medzhidov A.A., Kasumov V.T., Mamedov Kh.S. Sintez i issledovaniye khelatnykh soyedineniy metallov, soderzhashchikh prostranstvenno zatrudnennyy fenol. Kord. khimiya. 1981. T.7. №1. S. 66.

10. Bulatov M.I., Kalinkin I.P. Prakticheskoye rukovodstvo po fotokolorimetricheskim i spektrofotometricheskim metodam analiza. L.: Khimiya, 1986. S. 432.

\section{SKANDIUUUN(III) 2-HIDROKSİ-5T-BUTILFENOL-4'-METOKSİAZOBENZOLLA KOMPLEKSİ ŞəKLINDə EKSTRAKSIYALI QATILAŞDIRILMASI Və ONUN ATOM ABSORBSIYA ÜSULU ILO TOYINI}

\section{A.M.Paşacanov, S.İ.Niftaliyev, M.M.Ağamaliyeva, Ş.M.Bayramov, G.G.Abbasova, Z.A.Məmmədova}

Sc(III) 2-hidroksi-5T-butilfenol-4'-metoksiazobenzolla kompleksi alınmış və tədqiq edilmişdir. Kompleksin optimal şəraiti öyrənilmişdir. Đmələ gəlmiş kompleksin fiziki-kimyəvi, analitik xarakteristikaları hesablanmışdır. Molyar işıq udma əmsalı $(2.2-3.0) \cdot 10^{4}$. Davamlılıq sabiti $\beta_{\mathrm{k}}=2.8 \cdot 10^{10}$. Aparılmış tədqiqat işlərinə əsasən skandiumun müxtəlif nümunələrdə təyini metodikası işlənilmişdir. İşlənmiş metodikanın düzgünlüyü tərkibi məlum olan Dövlət standart nümunələrində skandiumu təyin etməklə yoxlanılmışdır.

Açar sözlor: skandium, atom absorbsiya, ekstraksiya üsulu, kompleksəməlogəlmə.

\section{ЭКСТРАКЦИОННОЕ КОНЦЕНТРИРОВАНИЕ СКАНДИЯ(ІІІ) В ФОРМЕ КОМПЛЕКСА С 2-ГИДРОКСИ-5-Т-БУТИЛФЕНОЛ-4'-МЕТОКСИАЗОБЕНЗОЛОМ И ЕГО АТОМНО- АБСОРБЦИОННОЕ ОПРЕДЕЛЕНИЕ}

\section{А.М.Пашаджанов, С.И.Нифталиев, М.М.Агамалиева, Ш.М.Байрамов, Г.Г.Аббасова, З.А.Мамедова}

Атомно-абсорбционным и спектрофотометрическим методами исследовано комплексообразование скандия 2 гидрокси-5-Т-бутилфенол-4'-метоксиазо-бензолом (HR). Найдены оптимальные условия образования и экстракции комплекса. Максимум светопоглощения комплекса в Молярный коэффициент поглощения равен $(2.2-3.0) \cdot 10^{4}$. Константа устойчивости комплекса скандия в $H_{-}$ бутаноле $\beta л=2.8 \cdot 10^{10}$. Разработана селективная и чувствительная методика экстракционно-атомно-абсорбционного определения скандия в почвах.

Ключевые слова: скандий, атомно-абсорбичионный метод, экстракияя, комплексообразование. 